\title{
LGBT+ Individuals' Sexual and Mental Health: A Comparison with Hetereosexual Group
}

\author{
Nur Elçin Boyacıoğlu' (D, Hüsniye Dinç' (D), Neslihan Keser Özcan' (D), Ardıl Bayram Șahin² (D) \\ 'Istanbul University - Cerrahpasa, Health Science Faculty, Istanbul, Turkey \\ ${ }^{2}$ Istanbul University School of Medicine, Istanbul, Turkey \\ ORCID IDs of the authors: N.E.B. 0000-000I-8I38-7347, H.D. 0000-0002-846I-643X, N.K.Ö. 0000-0003-I3II-6646, A.B.Ș. 0000-0003- \\ 4515-7530.
}

Cite this article as: Boyacıoğlu NE, Dinç H, Özcan NK, Șahin AB. LGBT+ Individuals' Sexual and Mental Health: A Comparison with Hetereosexual Group. Cyprus J Med Sci 2020; 5(3): 189-95.

\section{BACKGROUND/AIMS}

Although lesbian, gay, bisexual, and transgender (LGBT+) individuals experience many sexual and mental health problems, these problems are neglected by health professionals. We designed this study to determine the sexual and mental health problems of LGBT+ individuals by conducting a comparison with heterosexual individuals.

\section{MATERIAL and METHODS}

This cross-sectional, descriptive, and comparative study design was conducted between August 2015 and October 2015 ; it involved 210 LGBT+ subjects and 226 heterosexual subjects. Data were collected using online surveys, including an information form ( 35 questions) and the Turkish adaptation of a standard General Health Questionnaire (GHQ-12 questions). The GSQ-12 is a screening device for identifying minor psychiatric disorders in the general population. Descriptive statistics, independent sample t-test, and Spearman and Pearson's correlation test were used for data analyses.

\section{RESULTS}

Compared to the control group subjects, more LGBT+ subjects indulged in sexual activities for money and/or drugs; in addition, the prevalence of sexually transmitted diseases (STDs), experiences of abuse, and sexual problems was higher in LGBT+ subjects. There was no difference between the groups in terms of mental health status.

\section{CONCLUSION}

While there was a difference in the sexual health parameters between the groups, there was no difference in their mental health status.

Keywords: LGBT, mental health, sexual health

\section{INTRODUCTION}

Lesbian, gay, bisexual, transgender, transsexual, queer, questioning, intersex, inter-gender, asexual, ally and beyond (LGBT+) is a term that encompasses all groups and identities defined as "sexual minorities" (I). For the most part of history, even in the definitions given by the scientific community, homosexuality was defined using negative terms, such as sexual identity disorder, illness, and perversion. The removal of homosexuality from the classification as a disease was performed in steps. In 1952, the Diagnostic and Statistical Manual of Mental Disorders (DSM) of the American Psychiatric Association described homosexuality as a sociopathic personality disorder, while in the DSM-II (1968), it was classified as a sexual deviation. With the effect of dissenting views rising in the 1970s, the homosexuality category left its place to the sexual orientation disorder in 1973 in the DSM-II and this category, in turn, left its place to the category of ego dystonic homosexuality category in 1980 in the DSM-III. Finally, in the DSM-III-R (1987), homosexuality was no longer defined as a mental disorder. However, there are still traces of such negative references in clinical practice $(2,3)$.

The historical process in the definition of transsexuality is similar to that of homosexuality. Initially, the definition of transsexuality was included in the DSM-III and evaluated in the DSM-IV in the category of sexual identity disorders. Finally,

Presented in: I. LGBTi Ruh Sağlığı Sempozyumu, Bilgi Üniversitesi, Santral İstanbul. 
the word "disorder" was removed and redefined as "gender dysphoria" and separated from the paraphilias and sexual dysfunctions category. In time, psychiatry continues to make changes related to the definition of "sexual orientation" and "gender identity", still causing the individual to be stigmatized. In Turkey, in the diagnosis and identification of diseases, mental health specialists consider the DSM criteria $(2,3)$.

In the literature, the term LGBT is used instead of the term homosexuality. The reason for this is that the term homosexuality only brings sexuality to mind and disease diagnosis is perceived as categorization. Moreover, the term homosexuality was abandoned because it only included gay and lesbian individuals. Thus, the term "LGBT" was then used in Western societies (I).

Although not classified as having a disorder, LGBT+ individuals in Turkey are the target of prejudice and discrimination in many societies; they are ostracized and stigmatized by these societies. This situation causes sexual and psychological health problems in the LGBT+ individuals (4-6).

In our country, LGBT+ individuals had experiences similar to those worldwide. LGBT+ individuals started to form small groups outside the public dominion to come together with individuals going through the same experiences so that they could share problems and seek solutions. However, the process of organizing (or creating) a society in Turkey started only 120 years previously for LGBT+ individuals. They took the first step by becoming visible through the establishment of two associations in the metropolises of Turkey, Istanbul, and Ankara. Thereafter, LGBT+ associations were established in many other cities. Today, there are nine non-governmental organizations in Turkey established by LGBT+ individuals (6).

In most studies performed on LGBT+ individuals, the basis of the problems was stated to be discrimination, lack of social support, health inequalities, and minority stress arising from the fact that this group is neglected by health professionals (7-II).

The results of studies examining the sexual and mental health of LGBT+ individuals are varied. Some studies state that having a different sexual identity affects an individual's sexual and mental life negatively; while some state that the sexual and mental health of the group is no different from those of their heterosexual counterparts (9).

Few studies have assessed the needs and priorities of LGBT+ individuals, especially those regarding the provision of their health-related service needs. These research data are very important since they represent a study in Turkey that evaluated

\section{Main Points:}

- These results give data on LGBT individuals' sexual health in Turkey.

- These results give data on LGBT individuals' mental health in Turkey.

- This data enables to compare sexual and mental health outcomes for LGBT individuals and heterosexual individvals. both the sexual and mental health and provides the opportunity to compare these data to those of heterosexual individuals. We believe that our results can bridge the knowledge gap on the subject, present a clear picture of the existing situation, and help establish regulations on the issue.

This study aimed to determine the sexual and mental health problems of LGBT+ individuals by conducting a comparison with heterosexual individuals.

The following research questions were addressed by this study:

I. Is the adult LGBT+ population of Turkey more likely to experience sexual problems than the non-LGBT+ adult population?

2. Is the adult LGBT+ population of Turkey more likely to experience mental health problems than the non-LGBT+ adult population?

\section{MATERIALS AND METHODS}

\section{Research Design}

This cross-sectional, descriptive, and comparative study design was conducted from August 2015 to October 2015.

\section{Participants}

The sample included 210 LGBT+ and 226 heterosexual individuals. We did not use any sample calculation method to determine the sample because there are few associations operating in Turkey and only three of these associations share our work with its members. The average number of members of these associations is 600 (Istanbul LGBTI Solidarity Association: 50 members, Lambda Istanbul: 250 members and KaoS GL: 250 members).

As per the inclusion criteria, individuals aged $>18$ years who belonged to the LGBT+ community in Turkey, were able to understand questions about sexual and mental health, and could report her/his opinions were included. Those adults in personal and occupational mail groups in Turkey who did not identify themselves as LGBT+, were able to understand questions about sexual and mental health, and could report her/his opinions were included as controls.

\section{Instruments}

Data were collected using online self-reported questionnaires consisting of an information form (35 questions) and the Turkish version of the General Health Questionnaire-I2 (GHQ-I2) (I2 questions). In the first part of the questionnaire, detailed information regarding the study aim and contact information of the researchers were provided.

\section{Information Form}

For both the LGBT+ and the control group, six questions regarding the socio-demographic information, three questions evaluating their habits (smoking, alcohol, substance), twenty questions regarding sexuality (sexual orientation, gender identity, masturbation, age of first sexual experience) and sexual health (sexually transmitted diseases [STD], condom use, sexual health problems, and help seeking behavior), and six questions regarding abuse (physical, emotional, economical, and sexual abuse, childhood physical and sexual abuse) were asked. 
The responses were to be given by choosing from multiple choices.

\section{The General Health Questionnaire (GHQ-I2)}

GSA was used as a first-step screening test in social studies to determine the mental state of individuals without any psychiatric or physical problems. The scale was also preferred in this study because of its short and comprehensible use in social studies. The Turkish validity and reliability study of the GHQ-12 was performed in 1996 by Kilic (12). It contained 12 questions in four fields, including depression, anxiety, obsessively observed behavior, and hypochondriasis. Each GHQ-12 item was formulated as a statement about symptoms experienced during "the last weeks" (rather than "recently" as in the original questionnaire), with four response options, six of which were positively phrased and six of which were negatively phrased. Each item was answered by choosing from among 4 choices, ranging from "less than usual (0 point)", "no more than usual (0 point)", "rather more than usual (I point)", and "much more than usual (I point)". We mainly used a bimodal scoring method, whereby "less than usual" and "no more than usual" were both worth zero points and "rather more than usual" and "much more than usual" were worth one I point each. Accordingly, the lowest possible score was 0 , while the highest possible score was 12 .

\begin{tabular}{|c|c|c|c|c|}
\hline & $\begin{array}{l}\text { LGBT } \\
\text { group } \\
(210) \\
n(\%)\end{array}$ & $\begin{array}{l}\text { Control } \\
\text { group } \\
(226) \\
n(\%)\end{array}$ & $\begin{array}{l}\text { Chi- } \\
\text { Square }\end{array}$ & $\mathbf{P}$ \\
\hline \multicolumn{5}{|l|}{ Marital Status } \\
\hline Married & $13(6.2)$ & $69(30.5)$ & 46.70 & 0.001 \\
\hline Single & $191(91)$ & $148(65.5)$ & & \\
\hline Single (divorced, widowed) & $6(2.9)$ & $7(3.1)$ & & \\
\hline \multicolumn{5}{|l|}{ Education } \\
\hline Primary & I (0.5) & $2(0.9)$ & 31.87 & 0.001 \\
\hline Secondary - high school & $75(35.8)$ & $31(13.7)$ & & \\
\hline University & $134(63.8)$ & $193(85.4)$ & & \\
\hline \multicolumn{5}{|l|}{ Status of employment } \\
\hline Regular & $75(35.7)$ & $137(60.6)$ & 27.29 & 0.001 \\
\hline Irregular & $85(40.5)$ & $59(26.1)$ & & \\
\hline Unemployed/student & $50(23.8)$ & $30(13.3)$ & & \\
\hline \multicolumn{5}{|l|}{ Smoking (during last month) } \\
\hline Regular use & $125(59.5)$ & $96(42,5)$ & 19.69 & 0.001 \\
\hline Sometimes & $29(13.8)$ & $30(13.3)$ & & \\
\hline Not use & $56(26.7)$ & $100(44.2)$ & & \\
\hline \multicolumn{5}{|l|}{ Drug use (during one year) } \\
\hline Not use & $149(7 \mathrm{l})$ & $197(87.2)$ & 17.57 & 0.001 \\
\hline Use & $51(29)$ & $29(22.8)$ & & \\
\hline \multicolumn{5}{|l|}{ Alcohol use } \\
\hline Regular use & $35(16.7)$ & $24(10.6)$ & 14.58 & 0.002 \\
\hline Sometimes & $155(73.8)$ & $152(67.3)$ & & \\
\hline Not use & $20(9.5)$ & $50(22.1)$ & & \\
\hline
\end{tabular}

Those who scored $<2$ points were classified as having negative psychological health status, those who scored 2-3 points were classified as having mid-level psychological health status, and those scored $>4$ points were classified as having a highly positive psychological health status. The Cronbach alpha coefficient of the scale in the current study was 0.75 .

\section{Procedure}

The questionnaire was prepared for the study that was planned as an online survey, and the announcement was made on the Web pages of a few associations where LGBT+ individuals were members as well as via in mail groups belonging to LGBT+ groups. For heterosexual individuals, the aim of the study was explained and announcements were made in certain personal and occupational mail groups to achieve participation through the snowball method.

\section{Statistical Analysis}

Data were analyzed using the Statistical Package for the Social Sciences version 20.0 (SPSS Inc.; Chicago, IL, USA). In addition to descriptive statistics (mean, percentage, frequency), independent sample t-test and chi-square were used to compare the groups. Statistical significance was determined at $p \leq 0.05$.

\section{Ethical Considerations}

Ethical permission was obtained from the ethics board of the Medipol University before the study was initiated (Protocol Number: 10840098-604.01.01-E.1884). The study was carried out in accordance with the principles of the Helsinki Declaration, and approval was obtained at the beginning of the survey to enroll participants using the digital approach. Participants who were willing to participate in the study completed the questionnaires after providing consent.

\section{RESULTS}

\section{Socio-Demographic and Other Characteristics}

The average age of the LGBT+ individuals was 24.3I (SD=6.44), and the average age of the control group was 27.5I ( $S D=6.24)$. There was a significant difference in the age of the two groups $(t=6.47, p<0.001)$.

Among the LGBT+ individuals, $38.1 \%(n=80)$ stated their sexual orientation as bisexual, $59 \%(n=124)$ as homosexual, and $2.9 \%(n=6)$ as heterosexual; all the controls reported being heterosexual.

Among the LGBT+ individuals, $41 \%(n=80)$ stated their gender identity as male, 35.2\% $(n=74)$ as female, $6.7 \%(n=14)$ as trans male, and $3.3 \%(n=7)$ as trans female. Total $5.7 \%(n=12)$ stated that they did not feel a part of any gender, and $8.1 \%(n=17)$ did not respond to this question.

LGBT+ individuals were found to marry less, receive less education, work with less regularity (more unemployment); they used more tobacco, alcohol, and illicit drugs than heterosexual subjects (Table I).

\section{Characteristics Regarding Sexuality and Sexual Health}

LGBT+ individuals were found to masturbate more, have more STDs, enter more sexual relations for money/drugs, and experience more sexual problems than the controls. In the matter of 
taking professional help for sexual problems, no statistical differences were found between the groups (Table 2).

Total $10.4 \%$ of the LGBT+ individuals $(n=22)$ and $19 \%(n=45)$ of the control group never had sexual relations. Among the LGBT+

\begin{tabular}{|c|c|c|c|c|}
\hline & $\begin{array}{l}\text { LGBT } \\
\text { group } \\
(210) \\
\mathrm{n}(\%)\end{array}$ & $\begin{array}{l}\text { Control } \\
\text { group } \\
(226) \\
n(\%)\end{array}$ & $\begin{array}{l}\text { Chi- } \\
\text { Square }\end{array}$ & $\mathbf{P}$ \\
\hline \multicolumn{5}{|c|}{ Masturbation } \\
\hline Yes & $192(91.4)$ & $169(74.8)$ & 66.73 & 0.001 \\
\hline No & $18(8.6)$ & $57(25.2)$ & & \\
\hline \multicolumn{5}{|c|}{ Ideas on masturbation } \\
\hline Positive & |5| (71.9) & $167(73.9)$ & 1.61 & 0.445 \\
\hline Negative & $16(7.6)$ & $22(9.7)$ & & \\
\hline Neutral & $43(20.5)$ & $37(16.4)$ & & \\
\hline \multicolumn{5}{|c|}{ Use of condom } \\
\hline Yes & $68(37.5)$ & $73(40.8)$ & 10.42 & 0.015 \\
\hline No & $55(29.3)$ & $68(37.5)$ & & \\
\hline Sometimes & $61(33.2)$ & $40(21.7)$ & & \\
\hline \multicolumn{5}{|c|}{ Sexually transmitted diseases } \\
\hline Yes & $45(24.4)$ & $16(8.6)$ & 33.12 & 0.001 \\
\hline No & $143(75.6)$ & $165(91.4)$ & & \\
\hline \multicolumn{5}{|c|}{ Sex for money or drug } \\
\hline Yes & $18(8.6)$ & $3(1.3)$ & 300.7 & 0.001 \\
\hline No & $192(91.4)$ & $223(98.7)$ & & \\
\hline \multicolumn{5}{|c|}{ Problem of sexual life } \\
\hline Yes & $95(50.5)$ & $53(29.4)$ & 25.09 & 0.001 \\
\hline No & $93(49.5)$ & $127(80.6)$ & & \\
\hline \multicolumn{5}{|c|}{ Professional support for sexual problems } \\
\hline Yes & $5(26.6)$ & $5(27.7)$ & 5.02 & 0.081 \\
\hline No & $183(73.4)$ & $175(72.3)$ & & \\
\hline
\end{tabular}

\begin{tabular}{|c|c|c|}
\hline & $\begin{array}{c}\text { LGBT group } \\
(188) \\
n(\%)\end{array}$ & $\begin{array}{c}\text { Control group } \\
(181) \\
n(\%)\end{array}$ \\
\hline Had no sexual dysfunction & $89(47.3)$ & $126(69.5)$ \\
\hline Loss of libido & $32(17)$ & $22(12.1)$ \\
\hline Difficulty in arousal & $10(5.3)$ & I (0.6) \\
\hline Vaginismus & I $(0.59$ & I (0.6) \\
\hline Pain during intercourse & $2(I . I)$ & $3(1.7)$ \\
\hline Difficulty in orgasm & $10(5.3)$ & $8(4.4)$ \\
\hline Difficulty keeping an erection & $9(4.8)$ & $5(2.8)$ \\
\hline Premature/difficulty ejaculation & $10(5.3)$ & II (6.1) \\
\hline Avoiding due to the anal intercourse & II (5.9) & $0(0)$ \\
\hline Avoiding due to the STI & $4(2.2)$ & $0(0)$ \\
\hline Other & $10(5.3)$ & $4(2.2)$ \\
\hline
\end{tabular}

individuals who previously had sexual relationships, 9\% ( $n=19)$ had experienced gonorrhea, $8.1 \%(n=17)$ had genital warts, $1.4 \%$ $(n=3)$ were HIV positive, and $1 \%(n=2)$ had hepatitis. Among heterosexual individuals, $4 \%(n=9)$ had genital warts, and $0.4 \%$ $(n=I)$ experienced gonorrhea. Some of those who experienced STDs but did not define the type stated that they did not want to name the disease or did not know the name of the disease. The sexual problems encountered are listed in (Table 3); the most widely experienced problem in both the groups was that of interest and desire. The average age at the time of first sexual experience in the LGBT+ individuals was 16.31 years $(S D=3.50)$ and that in the controls was $19.63(S D=3.76)$. LGBT+ individuals had their first sexual experience earlier $(t=8.54, p<0.00 \mathrm{I})$.

\section{Abuse Experience and General Health Status}

The LGBT+ group was exposed to more physical and sexual abuse during childhood and to more physical and emotional

\begin{tabular}{|c|c|c|c|c|}
\hline & $\begin{array}{l}\text { LGBT } \\
\text { group } \\
(210) \\
\mathrm{n}(\%)\end{array}$ & $\begin{array}{l}\text { Control } \\
\text { group } \\
(226) \\
n(\%)\end{array}$ & $\begin{array}{l}\text { Chi- } \\
\text { Square }\end{array}$ & $p$ \\
\hline \multicolumn{5}{|l|}{ Physical Violence } \\
\hline Yes (partner) & $31(14.8)$ & $20(8.8)$ & 19.37 & 0.001 \\
\hline Yes (except partner) & $63(30)$ & $36(15.9)$ & & \\
\hline No & $116(55.2)$ & $170(75.2)$ & & \\
\hline \multicolumn{5}{|l|}{ Psychological Violence } \\
\hline Yes (partner) & $4 \mid(19.5)$ & $34(15)$ & 57.06 & 0.001 \\
\hline Yes (except partner) & $112(53.3)$ & $52(23)$ & & \\
\hline No & $57(27.2)$ & $140(62)$ & & \\
\hline \multicolumn{5}{|l|}{ Economical Violence } \\
\hline Yes (partner) & $12(5.7)$ & $13(5.8)$ & 2.36 & 0.306 \\
\hline Yes (except partner) & $37(17.6)$ & $28(12.4)$ & & \\
\hline No & $161(76.7)$ & $185(81.8)$ & & \\
\hline \multicolumn{5}{|l|}{ Forced sex } \\
\hline Yes (partner) & $18(8.5)$ & $8(3.5)$ & 17.04 & 0.001 \\
\hline Yes (except partner) & $22(10.5)$ & $6(2.7)$ & & \\
\hline No & $170(81)$ & $212(93.8)$ & & \\
\hline \multicolumn{5}{|c|}{ Physical Abuse in childhood } \\
\hline Yes (family) & $40(19)$ & $22(9.7)$ & 16.72 & 0.001 \\
\hline Yes (except family) & $40(19)$ & $24(10.6)$ & & \\
\hline No & $130(62)$ & $180(79.7)$ & & \\
\hline \multicolumn{5}{|c|}{ Sexual Abuse in childhood } \\
\hline Yes (family) & $9(4.3)$ & $2(0.9)$ & 30.55 & 0.001 \\
\hline Yes (except family) & $57(27.1)$ & $21(9.3)$ & & \\
\hline No & $144(68.6)$ & $203(89.8)$ & & \\
\hline \multicolumn{5}{|l|}{ General Health Status } \\
\hline Low & $90(42.9)$ & $103(45.6)$ & 2.80 & 0.246 \\
\hline Mid & $39(18.6)$ & $52(23)$ & & \\
\hline High & $81(38.5)$ & $71(31.4)$ & & \\
\hline
\end{tabular}


abuse as adults; they were also forced more into sexual relationships than the controls. Although LGBT group had higher (negative psychological health) GSQ scores, there was no statistically significant difference between the groups (Table 4).

\section{DISCUSSION}

Discussion of the Socio-Demographic and Other Characteristics Fewer LGBT+ individuals got married; they received less education, worked less regularly (more unemployment), and used more tobacco, alcohol, and illicit drugs than the controls. These differences in the demographic data were evaluated as results of the social problems experienced by LGBT+ individuals, such as stigmatization and discrimination.

In the present study, the use of tobacco and alcohol was more prevalent in LGBT individuals. The prevalence of smoking among LGBT+ individuals varies between $26.47 \%$ and $61 \%(13$, $14)$, that of alcohol use varies between $65 \%$ and $84 \%(15,16)$, and that of illicit drug use varies between $9.7 \%$ and $53.3 \%(17,18)$. The reported rates vary in a very large range. The same wide perspective applies to the habits of heterosexual individuals. It is very difficult to make comparisons regarding the use of alcohol, tobacco, and drugs. Many factors, such as the age group, race, employment status, income level, and region of residence affect the alcohol, tobacco, and drug use; the multitude of influencing factors make the comparison challenging $(13-15,19,20)$. However, the generally reported alcohol, tobacco, and drug use rates for LGBT+ individuals are higher than those for the population as a whole. This situation is believed to be a negative coping method used to deal with problems arising because of sexual orientation or gender identity differences.

\section{Discussion of Characteristics Regarding Sexuality and Sexual Health}

There is no direct relationship between STDs and sexual orientation-gender identity. Sexually transmitted infections may infect anyone, and the clinical symptoms do not vary as per the sexual orientation. Suggestions for avoiding STDs do not differ for LGBT+ individuals, and the determining factor in infection is the cause rather than the person. Risks are high for anyone who engages in unprotected sex (2I). LGBT+ individuals experience more STDs, enter more sexual relations for money/drugs, and use condoms more frequently. These differences may be attributable to the inclusion of LGBT+ sex workers in our sample. These individuals are more aware about condom use after experiencing an STD. Studies show that the rate of HIV positivity is higher among LGBT+ individuals $(18,22-24)$. However, in these studies, risk factors, such as young age, homelessness, frequent changing of sexual partners, and predilection for risky behavior were more stressed than the factor of belonging to the LGBT+ community.

The prevalence of sexual dysfunction among LGBT+ groups was $42.5 \%-79 \%(7,8,25-27)$. When the high rates of childhood sexual abuse and STDs among LGBT+ individuals are considered, these rates are not surprising $(8,9)$. In a recent systematical review, studies examining sexual health problems in LGBT+ individuals were stated to be lacking and the existing studies are criticized for not including heterosexual control groups (9). Thus, the existing studies should be carefully interpreted.
Problems endemic to LGBT+ individuals who are exposed to discrimination in every field of life are unknown or are examined sufficiently by health care workers. Sexual problems are among the most important problems health issues that they experience. In the present study, the most widely experienced problem in both the groups was that of sexual interest and desire. This result is similar to that reported in the literature $(8,25-27)$.

\section{Discussion of the Findings Regarding Abuse Experience and General Health Status}

The finding that the LGBT+ group underwent more abuse of every kind in every phase of their lives (childhood, adulthood, marriage, work life, social life etc.) compared to the control group is consistent with several previous reports. For example, in a national study conducted by Andersen and Blosnich (28) in the USA, where the greatest numbers of studies on the subject have been conducted, LGBT+ individuals were found to be exposed to $60 \%$ more childhood abuse (physical, sexual, emotional) compared to heterosexual subjects. Similarly, in a study where the peer bullying experienced by heterosexual and LGBT+ individuals during childhood in Australia were compared, LGBT+ individuals were found to be exposed to more peer bullying (29).

A systematical review by Rothman et al. (30) in the USA that examined 75 studies found that lesbian and bisexual women were sexually attacked more often during adulthood and during their entire lifetime than heterosexual individuals (30). In another study on 1243 LGB individuals in the USA, sexual minorities were reportedly exposed to more abuse during both, childhood and adulthood (3I). In addition, most studies that have investigated the abuse of LGBT individuals in the literature focus on spousal violence, with high reported abuse rates (32-35). In a study on LGBT+ individuals in Turkey, they were exposed to violence because of their sexual orientation; $23 \%$ were exposed to physical violence, $87 \%$ to social violence, and $50 \%$ to violence from people they did not know (36). According to another study conducted in Turkey, the rate of people exposed to familial violence because of their sexual orientation and/or gender identity was $6.6 \%$, while the rate of those who received death threats from their families was $3.2 \%$ (4).

Both national and international data point to the seriousness of the issue. However, regardless of group, care should be given to comparing data on violence. Some studies focus on certain types of violence encountered by LGBT individuals $(34,35)$, while some only evaluate a certain group of LGBT+ individuals (such as only gay or lesbian people) (3l-33). Some studies have focused on spouse violence, while others have evaluated social violence (29) or made evaluations pertaining to different time periods (lifelong, previous 5 years, and previous I year).

In this study, 45.6\% LGBT individuals had poor general health status. However, no meaningful difference was found on comparison to the heterosexual group. In a study by Yalcinoglu and Onal (3) in Turkey on 210 homosexual/bisexual males, this rate was higher than that in our study (65.3\%). Most studies on LGBT+ individuals have focused on the relationship between discrimination and negative health outcomes. Two different systematical reviews performed in this context have shown that discrimination is related to low mental health status $(37,38)$. 
In many studies performed on LGBT+ individuals, the rates of many mental problems, such as depression and suicide (39-4I); nicotine, alcohol, and substance use $(40,41)$; sexual activity under the influence of alcohol or substances (42); anxiety disorders (40); schizophrenia/psychotic disorders (40); eating disorders (43); and PTSD $(44,45)$ were higher than those in heterosexual individuals.

Although there is much evidence showing that LGBT+ individuals have worse health status than heterosexual individuals, the present results do not support this statement. Most of the people who participated in the study were related to LGBT+ associations and may have created a selection bias. LGBT+ individuals who faced negative attitudes from the society, such as discrimination and exclusion, have come together to raise their own awareness, become organized, and seek their rights. This may have led to better maintenance of their social and psychological health as compared to that of those who remained outside this process.

LGBT+ individuals who are at a distinct disadvantage compared to heterosexuals had lower marriage rates, received less education, worked less regularly (higher unemployment rate), and used more tobacco, alcohol, and illicit drugs than heterosexual individuals. With regard to sexual health, LGBT+ individuals experienced more STDs, entered more sexual relations for money/drugs, encountered more sexual problems, and had higher exposure to more abuse during childhood and adulthood; however, their health status was not inferior to that of heterosexual individuals despite the above-mentioned negative aspects. Many previous studies have reported poorer health status of LGBT individuals, and the contradictory results of our study are believed to be attributed to the fact that our sample comprised LGBT+ individuals who were receiving support from civil society organizations formed to defend their rights.

\section{Clinical Implication}

This study may raise awareness on the questioning of the widespread heterosexist approach that accepts heterosexuality as the only acceptable, healthy, and right sexual orientation, with LGBT+ groups being one of the disadvantaged groups with regard to health. It can also remove barriers to healthcare professionals in offering sexual and mental health care without prejudice and objective service to LGBT individuals.

\section{Study Limitations}

The current study presents some limitations; therefore, the results should be interpreted cautiously. A Web-based survey was used for sample selection; consequently, only volunteers with internet access were able to participate. Sexual orientation minority status was based on self-identified sexual orientation only.

The sexual function disorders of the participants were determined via self-reporting; this may have resulted in over reporting. The mental health of the participants was determined through a valid and reliable scale; however, no evaluation was performed by a clinician.

In the study, the LGBT+ community individuals were evaluated as a group. Each letter in the abbreviation represents a different population; therefore, care should be taken while interpreting the study results. A significant difference between the groups in terms of age is another limitation of the study.
Ethics Committee Approval Ethical permission was obtained from Medipol University The Ethics Board before the study began (Protocol Number: 10840098-604.01.0I-E.1884).

Informed Consent: Written informed consent was obtained from patients who participated in this study.

Peer-review: Externally peer-reviewed.

Author contributions: Concept - N.E.B., H.D., N.K.Ö., A.B.S.; Design - N.B.E., N.K.Ö., H.D., A.B.Ș.; Supervision - N.E.B., H.D., N.K.Ö., A.B.Ș.; ResourceNone; Materials - None; Data Collection and/or Processing - A.B.S., N.E.B., H.D., N.K.Ö.; Analysis and/or Interpretation - N.K.Ö., N.E.B., H.D., A.B.Ș.; Literature Search - H.D., N.E.B., N.K.Ö., A.B.S.; Writing - N.E.B., HD, N.K.Ö, A.B.Ș.; Critical Reviews - N.E.B., HD, N.K.Ö., A.B.Ș.

Acknowledgements: We would like to thank all the participants for helping with recruitment for the study.

Conflict of Interest: The authors have no conflicts of interest to declare.

Financial Disclosure: The authors that this study has received no financial support.

\section{REFERENCES}

I. Kaos GL. What illness, what crime, what sin! LGBT Rights are Human Rights. 20ll Available from: URL: http://www.kaosgldernegi.org/ resim/kutuphane/dl/Igbt_haklari_insan_haklaridir_saglik.pdf

2. Guner U, Kalkan P, Oz Y, Ozsoy EC, Soyle F. Monitoring report: Discrimination based on sexual orientation or sex identity in Turkey. Istanbul: Istanbul Bilgi University Publications; 20ll.

3. Yalcınoglu N, Onal AE. The internalized homophobia level of the homosexual and bisexual men and its effect on the health. Turkish $\mathrm{J}$ of Public Health 2014; 12(2): 100-12. [CrossRef]

4. LGBTI Rights in Turkey Study. Lesbian, Gay, Bisexual and Transgen$\operatorname{der}($ LGBT) Individuals of Social and Economic Problems Research Summary Results in Turkey. Istanbul: Bilgi University Publications; 2014.

5. Senel B. Reflections of sexual orientation discrimination in everyday life. Master's Thesis, 2014.

6. Alp A. The participation of disadvantages groups' careers in Turkey: LGBTI individuals in Istanbul. Mugla Sitki Kocaman University Department of Sociology, Institute of Social Sciences, Thesis. 2015.

7. Shindel AW, Vittinghoff E, Breyer BN. Erectile dysfunction and premature ejaculation in men who have sex with men. J Sex Med 20I2; 9(2): 576-84. [CrossRef]

8. Ivankovic ' I, Ševic ' S, Štulhofer A. Distressing sexual difficulties in heterosexual and non-heterosexual Croatian men: Assessing the role of minority stress. J Sex Res 2015; 52(6): 647-58. [CrossRef]

9. Štulhofer A, Šević S, Doyle DM. Comparing the prevalence and correlates of sexual health disturbances among heterosexual and nonheterosexual men: An overview of studies. Sex Med Rev 20l4; 2(3-4): 102-II. [CrossRef]

10. Kaptan S. Homosexuals and mental health. Sexual education treatment and research association of information file. Homosexuality. Istanbul: Senk Offset Printing; 20I3.p.44-47.

II. Bostwick WB, Boyd CJ, Hughes TL, West BT, McCabe SE. Discrimination and mental health among lesbian, gay, and bisexual adults in the United States. Am J Orthopsychiatry 20l4; 84(I): 35-45. [CrossRef]

12. Kilıc C. General health Inventory: A validity and reliability study. Turk Psikiyatri Derg 1996; 7: 3-II.

13. Pelster ADK, Fisher CM, Irwin JA, Coleman JD, McCarthy MA. Tobacco use and its relationship to social determinants of health in LGBT populations of a Midwestern State. LGBT Health 2015; 2: 7I-6. [CrossRef] 
14. Tamí-Maury I, Lin MT, Lapham HL, Hong JH, Cage C, Shete S, et al. A pilot study to assess tobacco use among sexual minorities in Houston, Texas. Am J Addic 2015; 24(5): 391-95. [CrossRef]

15. Kelly J, Davis C, Schlesinger C. Substance use by same sex attracted young people: Prevalence, perceptions and homophobia. Drug Alcohol Rev 2014; 34(4): 358-65. [CrossRef]

16. Jones S. Drinking patterns and outcomes of alcohol use by LGBT students at a minority-serving university. In 43rd Biennial Convention Book, Las Vegas;2015.

17. Duncan DT, Hatzenbuehler ML, Johnson RM. Neighborhood-level LGBT hate crimes and current illicit drug use among sexual minority youth. Drug Alcohol Depend 2014; I35: 65-70. [CrossRef]

18. Kurka T, Soni S, Richardson D. High rates of recreational drug use in men who have sex with men. Sex Transm Infec 2015; 9I(6): 394. [CrossRef]

19. Fallin A, Goodin A, Lee YO, Bennett K. Smoking characteristics among lesbian, gay, and bisexual adults. Prev Med 2015; 74:123-30. [CrossRef]

20. Babineau K, Clancy L, Keogan S. Smoking among people living with HIV and AIDS in Ireland: Prevalence among sub-groups. Eur Respir J. 2015; 46(suppl 59): PA5I30. [CrossRef]

21. Basar K, Kaptan S. Myths related to sexual orientation. sexual education treatment and research association for information files, Homosexuality. Istanbul: Senk Offset Printing; 2013. pp.33-7.

22. Centers for Disease Control and Prevention (CDC). HIV among gay, bisexual and other men who have sex with men. 20l3. Available from: URL: http://www.cdc.gov/ hiv/pdf/risk_HIV_among_AA_ Gay_other.pdf

23. Nyamathi A, Reback CJ, Shoptaw S, Salem BE, Zhang S, Yadav K. Impact of tailored interventions to reduce drug use and sexual risk behaviors among homeless gay and bisexual men. Am J Mens Health 2015; II(2): 208-20. [CrossRef]

24. Brito MO, Hodge D, Donastorg Y, Khosla S, Lerebours L, Pope Z. Risk behaviours and prevalence of sexually transmitted infections and HIV in a group of Dominican gay men, other men who have sex with men and transgender women. BMJ Open 2015; 5(4): I-6. [CrossRef]

25. Lau JTF, Kim JH, Tsui HY. Prevalence and sociocultural predictors of sexual dysfunction among Chinese men who have sex with men in Hong Kong. J Sex Med 2008; 5: 2766-79. [CrossRef]

26. Mao L, Newman CE, Kidd MR, Saltman DC, Rogers GD, Kippax SC. Self-reported sexual difficulties and their associa- tion with depression and other factors among gay men attending high HIV-caseload general practices in Australia. J Sex Med 2009; 6(5): 1378-85. [CrossRef]

27. Hirshfield S, Chiasson MA, Wagmiller RLJ, Remien RH, Humberstone $M$, Scheinmann R, et al. Sexual dysfunction in an Internet sample of U.S. men who have sex with men. J Sex Med 20I0; 7(9): 3104-I4. [CrossRef]

28. Andersen JP, Blosnich J. Disparities in adverse childhood experiences among sexual minority and heterosexual adults: results from a multi-state probability-based sample. PLoS One 2013; 8(I): 1-7. [CrossRef]

29. Zou C, Andersen JP. Comparing the rates of early childhood victimization across sexual orientations: Heterosexual, lesbian, gay, bisexval, and mostly heterosexual. PLoS One 20I5; I0(I0): I-I5. [CrossRef]
30. Rothman EF, Exner D, Baughman AL. The prevalence of sexual assault against people who identify as gay, lesbian, or bisexual in the United States: A systematic review. Trauma Violence Abuse 20II; 12(2): 55-66. [CrossRef]

31. Lehavot K, Molina Y, Simoni JM. Childhood trauma, adult sexual assault, and adult gender expression among lesbian and bisexual women. Sex Roles 2012; 67(5-6): 272-84. [CrossRef]

32. Stephenson R, Rentsch C, Salazar LF, Sullivan PS. Dyadic characteristics and intimate partner violence among men who have sex with men. West J Emerg Med 20II; 12(3): 324-32.

33. Pantalone DW, Schneider KL, Valentine SE, Simoni JM. Investigating partner abuse among HIV-positive men who have sex with men. AIDS Behav 2012; 16(4): 1031-I043. [CrossRef]

34. Walters ML, Chen J, Breiding MJ. The National Intimate Partner and Sexual Violence Survey (NISVS): 2010 findings on victimization by sexual orientation. Atlanta, GA. Available from: URL: http://www. cdc.gov/violenceprevention/nisvs/ specialreports.html

35. Mimiaga MJ, Biello KB, Robertson AM, Oldenburg CE, Rosenberger $\mathrm{JG}, \mathrm{O}^{\prime}$ Cleirigh $\mathrm{C}$, et al. High prevalence of multiple syndemic conditions associated with sexual risk behavior and HIV infection among a large sample of Spanish-and Portuguese-speaking men who have sex with men in Latin America. Arch Sex Behav 2015; 44(7): 1869-78. [CrossRef]

36. Lambda. Neithter wrong nor alone. Homosexual And bisexual individuals' problems. Istanbul: Berdan Publications; 2006.

37. Paradies $Y$. A systematic review of empirical research on self-reported racism and health. Int J Epidemiol 2006; 35(4): 888-901. [CrossRef]

38. Williams $D$, Mohammed S. Discrimination and racial disparities in health: Evidence and needed research. J Behav Med 2009; 32(I): 20-47. [CrossRef]

39. Marshal MP, Dietz LJ, Friedman MS, Stall R, Smith HA, McGinley $\mathrm{J}$, et al. Suicidality and depression disparities between sexual minority and heterosexual youth: A meta-analytic review. J Adoles Health 20II; 49(2): II5-I23. [CrossRef]

40. Bolton SL, Sareen J. Sexual orientation and its relation to mental disorders and suicide attempts: Findings from a nationally representative sample. Can J Psychiatry 20II; 56(I): 35-43. [CrossRef]

4l. Burns MN, Ryan DT, Garofalo R, Newcomb ME, Mustanski B. Mental health disorders in young urban sexual minority men. J Adoles Health 2015; 56(I): 52-8. [CrossRef]

42. Herrick A, Marshal MP, Smith H, Stall R. Sex while intoxicated: A meta- analysis comparing heterosexual and SMY. J Adoles Health 2011; 48(3): 306-9. [CrossRef]

43. Austin SB, Ziyadeh NJ, Corliss HL, Rosario M, Wypii D, Haines J, et al. Sexual orientation disparities in purging and binge eating from early to late adolescence. J Adoles Health 2009; 45(3): 23845. [CrossRef]

44. Mustanski BS, Garofalo R, Emerson EM. Mental health disorders, psychological distress, and suicidality in a diverse sample of lesbian, gay, bisexual, and transgender youths. Am J Public Health 20I0; 100(12): 2426-32. [CrossRef]

45. Roberts AL, Rosario M, Corliss HL, Koenen KC, Austin SB. Elevated risk of posttraumatic stress in sexual minority youths: mediation by childhood abuse and gender nonconformity. Am J Public Health 2012; 102(8): 1587-93. [CrossRef] 